\title{
Potensi Penerapan Konsep Green Campus pada Atribut Green Open Space di Institut Teknologi Nasional (Itenas) Bandung
}

\author{
Enni Lindia Mayona, Bella Fernanda \\ Jurusan Perencanaan Wilayah dan Kota, Fakultas Teknik Sipil dan Perencanaan \\ ITENAS, Bandung \\ Email: elinda@itenas.ac.id
}

\begin{abstract}
ABSTRAK
Institut Teknologi Nasional (Itenas) merupakan salah satu perguruan tinggi yang memiliki visi untuk ikut berperan aktif dalam pembangunan berkelanjutan di lingkup nasional dan global. Pusat Studi Sumber Daya Alam dan Lingkungan (PUSDAL) Itenas menyatakan bahwa Itenas dianggap belum mampu merespon tantangan lingkungan saat ini, belum ada integrasi antara pusat studi dengan berbagai lumbung pengetahuan yang ada di jurusan, serta diperlukan perubahan institusi menuju arah pengembangan hijau. Oleh karena itu, perlu dilakukan penerapan konsep green campus dimulai dari atribut green open space menurut Program Pengembangan Kota Hijau (P2KH) oleh Kementerian Pekerjaan Umum (2017) yang peneliti anggap memiliki peranan penting dan krusial di dalam lingkungan kampus. Penelitian ini bertujuan untuk mengetahui potensi penerapan konsep green campus pada atribut green open space di Institut Teknologi Nasional (Itenas) Bandung. Pengumpulan data dilakukan melalui observasi langsung, penyebaran kuesioner, dan wawancara, sedangkan metode analisis yang digunakan adalah distribusi frekuensi, scoring, dan komparatif, juga Metode Gerarkis dan UI GreenMetric World University Rankings 2018. Hasil dari penelitian menunjukkan bahwa Itenas memiliki beberapa lokasi potensial ruang terbuka hijau, serta civitas akademika Itenas memiliki pengetahuan dan kepedulian yang tinggi, serta peran aktif yang sangat tinggi terhadap atribut green open space.
\end{abstract}

Kata Kunci: Green Campus, Green Open Space

\begin{abstract}
The National Institute of Technology (Itenas) is one of the universities that has a vision to contibute in sustainable development in the national and global scope. The Center of Study for Natural Resources and Environment (PUSDAL) stated that Itenas was unable to respond to current environmental challenges, there was no integration between study centers with various knowledge in the department, and institutional changes needed towards green development direction. Therefore, it is necessary to implement the green campus concept starting from attributes of green open space according to the Green City Development Program (P2KH) by Ministry of Public Works (2017) which researchers consider to have an important and crucial role in the campus environment. This study aims to determine the potential application of the green campus concept to the attributes of green open space in National Institute of Technology (Itenas) Bandung. Data collection is done through direct observation, questionnaires, and interviews, while the analytical methods used are frequency distribution, scoring, and comparative, also the Gerarkis Method and the UI GreenMetric World University Rankings 2018. The results of the study show that Itenas has several potential locations for green open space and the academic community of Itenas have high knowledge and concern, and a very high contibution on the attributes of green open space.
\end{abstract}

Keywords: Green Campus, Green Open Space 


\section{PENDAHULUAN}

Pemanasan global telah menyebabkan terjadinya perubahan iklim secara signifikan, seperti pada suhu udara dan curah hujan, sebagai isu utama lingkungan yang dihadapi dunia saat ini. Pemanasan global mengacu pada peningkatan suhu permukaan bumi, sebagai salah satu dampak dari tingginya emisi karbon dioksida yang disebabkan oleh manusia [1]. Berbagai fenomena alam yang cenderung mengalami penyimpangan terjadi pada beberapa daerah seperti iklim yang tidak menentu, hujan lebat yang menyebabkan banjir dan longsor, munculnya angin puting beliung, bahkan kekeringan berkepanjangan akibat suhu udara yang tinggi. Hal tersebut mengakibatkan semakin meningkatnya masalah lingkungan yang disebabkan oleh alam maupun oleh manusia. Salah satu program lingkungan yang akhir-akhir ini ditujukan untuk mengatasi masalah lingkungan adalah program green city.

Green city adalah konsep yang menekankan pada penanganan isu lingkungan dan keberlanjutan baik dari sisi ekonomi maupun gaya hidup. Pendekatan ini tidak hanya berfokus pada lingkungan yang bersifat alami tetapi juga bagaimana kota dan lahan di sekitarnya dapat dikembangkan lebih produktif. Konsep kota ini membantu kota menjadi lebih nyaman dan menjadi kota yang berkelanjutan [2]. Definisi tentang Green City seringkali digunakan sebagai istilah yang sama dengan "Eco-city" atau "Sustainable city [3]. Menurut Michelle de Roo dalam The Green City Guidelines: Techniques for a healthy liveable city [4], konsep green city dapat meningkatkan kebahagiaan dan kesehatan masyarakat karena mereka tinggal dan bekerja pada lingkungan yang asri. Manfaat psikologis tersebut meningkatkan kenyamanan masyarakat karena kualitas udara yang baik dan akses terhadap ruang hijau disekitarnya yang mudah memberi kemungkinan masyarakat untuk berolahraga atau sekedar berjalan kaki di luar ruangan tempat tinggalnya. Selain itu, konsep green city dapat meningkatkan interaksi sosial karena lingkungan yang lebih hijau dan asri akan mendorong masyarakat untuk menghabiskan lebih banyak waktu beraktivitas di ruang terbuka.

Pengembangan konsep pelestarian lingkungan umumnya dilakukan pada wilayah perkotaan, menyebabkan perlu dilakukannya pengembangan konsep tersebut secara lebih menyeluruh pada wilayah yang lebih spesifik dan lebih detail dalam skala spasial yang lebih kecil, seperti lingkungan perguruan tinggi dengan menerapkan program green campus. Green campus dilatarbelakangi oleh lingkungan kampus yang diharapkan menjadi tempat yang nyaman, bersih, teduh, indah, dan sehat untuk menimba ilmu pengetahuan, serta penggunaan sumber daya yang efisien. Keterlibatan seluruh civitas akademika dalam lingkungan kampus melalui adanya kesadaran dan kepedulian sangat penting dalam memelihara kelestarian lingkungan, mengingat kampus sebagai tempat berkumpulnya para intelektual dan tempat dilahirkannya para intelektual muda generasi penerus bangsa diharapkan dapat menjadi contoh bagi institusi maupun kawasan lain dalam pengelolaan lingkungan yang baik.

Salah satu perguruan tinggi yang memiliki visi untuk ikut berperan aktif dalam pembangunan berkelanjutan di lingkup nasional dan global adalah Institut Teknologi Nasional (Itenas) Bandung. Berdasarkan hal tersebut, Itenas akan menjadi lokasi penelitian potensi penerapan konsep green campus pada atribut green open space. Penelitian ini dilakukan untuk mengetahui kebutuhan ruang terbuka hijau menggunakan metode gerarkis dan UI GreenMetric World University Rankings 2018, mengetahui kebutuhan jumlah pohon, mengetahui pengetahuan, kepedulian, dan bentuk peran aktif civitas akademika, serta untuk mengetahui lokasi potensial bagi penyediaan ruang terbuka hijau. 


\section{TINJAUAN PUSTAKA}

\subsection{Konsep Green Campus}

Green campus merupakan suatu konsep yang mengutamakan pengelolaan kampus yang berkesinambungan dan berkelanjutan dengan memperhatikan aspek lingkungan guna meminimalisir dan mengantisipasi berbagai permasalahan lingkungan. Indikator terciptanya konsep green campus antara lain adanya kebijakan manajemen kampus yang berorientasi pada pengelolaan lingkungan, terpeliharanya kebersihan dan kenyamanan lingkungan, adanya penghijauan untuk mencapai proporsi ideal ruang terbuka hijau, adanya upaya penghematan penggunaan air, listrik dan kertas, penggunaan sistem transportasi ramah lingkungan (agar bebas polusi), adanya pengelolaan limbah (sampah), tersedianya bangunan ramah lingkungan, serta adanya kepedulian dan keterlibatan seluruh elemen civitas akademika dalam budaya peduli lingkungan.

\subsection{Atribut Green Open Space}

Green open space merupakan perwujudan kuantitas dan kualitas ruang terbuka hijau pada kawasan kampus. Ruang terbuka hijau pada area kampus termasuk pada ruang terbuka privat berupa taman pada halaman kampus dan pada atap bangunan. Menurut Peraturan Menteri Pekerjaan Umum Nomor : 05/PRT/M/2008 Tentang Pedoman Penyediaan dan Pemanfaatan Ruang Terbuka Hijau di Kawasan Perkotaan[2], RTH pada halaman bangunan dapat berupa pohon kecil (memiliki ketinggian sampai dengan 7 meter) atau sedang (memiliki ketinggian 7 sampai 12 meter) yang ditanam pada lahan (tanah) atau pada pot. RTH pada atap bangunan yaitu berupa tanaman yang tidak terlalu besar, dengan perakaran yang mampu tumbuh dengan baik pada media tanam yang terbatas dan tidak mengganggu struktur bangunan, tahan terhadap hembusan angin, serta relatif tidak memerlukan banyak air. Jenis tanaman yang dapat ditanam pada atap bangunan terdiri dari perdu dan semak. Penyediaan RTH pada kawasan kampus haruslah ideal yang disesuaikan dengan populasi kampus.

\subsection{UI GreenMetric World University Rankings 2018}

Universitas Indonesia (UI) mengawali sebuah Peringkat Universitas Dunia pada tahun 2010 yang kemudian dikenal dengan nama "UI GreenMetric World University Rankings" untuk mengetahui usaha berkelanjutan kampus. Secara umum, penilaian didasarkan pada konsep lingkungan, ekonomi dan persamaan agar indikator dan kategori pemeringkatan dapat relevan bagi seluruh kampus. Tujuan pemeringkatan ini adalah untuk [5]:

a. Berkontribusi dalam wacana berkelanjutan dalam bidang pendidikan dan penghijauan kampus;

b. Mempromosikan universitas sebagai agen perubahan sosial yang berkaitan dengan tujuan-tujuan berkelanjutan;

c. Menjadi alat penilaian diri tentang keberlanjutan kampus untuk Institusi Pendidikan Tinggi; dan

d. Menginformasikan kepada pemerintah, badan lingkungan setempat, masyarakat, serta internasional mengenai program-program berkelanjutan di kampus.

Pada UI GreenMetric World University Rankings 2018 [5], terdapat 6 kategori yang terdiri dari Penataan dan Infrastruktur (SI), Energi dan perubahan iklim (EC), Limbah (WS), Air (WR), Transportasi (TR), serta Pendidikan dan Penelitian (ED). Kategori yang akan digunakan pada penelitian ini adalah kategori penataan dan infrastruktur. 


\subsection{Kategori Penataan dan Infrastruktur}

Penataan dan infrastruktur terkait ruang terbuka hijau bertujuan untuk memicu kampus dalam menyediakan lebih banyak ruang terbuka hijau untuk penghijauan dan menjaga lingkungan secara berkelanjutan yang dapat dilihat pada indikator kategori penataan dan infrastruktur berdasarkan UI GreenMetric World University Rankings 2018 yang dijelaskan pada Tabel 1 berikut [5].

Tabel 1. Indikator Kategori Penataan dan Infrastruktur [5]

\begin{tabular}{ll}
\hline No. & \multicolumn{1}{c}{ Indikator } \\
\hline Penataan dan Infrastruktur \\
\hline S 1 & Perbandingan antara ruang terbuka dengan total area \\
S 2 & Persentase area kampus yang berupa hutan \\
S 3 & $\begin{array}{l}\text { Persentase area kampus yang ditutupi dengan tanaman/taman (termasuk rumput, kebun, dan } \\
\end{array}$ \\
lain-lain) & $\begin{array}{l}\text { Persentase area permukaan di lingkungan kampus yang dapat menyerap air (termasuk tanah } \\
\text { S } 4 \text { atau con-block) }\end{array}$ \\
S 5 & Total ruang terbuka dibagi dengan populasi kampus \\
S 6 & Persentase budget kampus untuk mewujudkan kampus yang berkelanjutan (ramah lingkungan) \\
\hline
\end{tabular}

\section{METODOLOGI PENELITIAN}

\subsection{Jenis Penelitian}

Penelitian ini menggunakan metode analisis deskriptif dengan pendekatan kuantitatif dan kualitatif. Metode deskriptif digunakan untuk menggambarkan suatu fenomena dengan membuat deskripsi secara sistematis, faktual, dan akurat mengenai fakta dan sifat suatu populasi [6]. Metode ini dilakukan dengan mengumpulkan data, menganalisis data, dan menginterpretasikan hasil dari analisis data tersebut.

Pendekatan kuantitatif dan kualitatif (mixed method) yaitu metode kuantitatif berupa angka-angka yang didapat secara akurat berdasarkan fenomena yang terukur, sedangkan metode kualitatif untuk memahami makna dibalik data yang tampak dan memahami interaksi sosial [7]. Metode kuantitatif dan kualitatif digunakan secara bergantian, dimulai dari metode kuantitatif yang digunakan pada saat identifikasi dan perhitungan kebutuhan ruang terbuka hijau, serta analisis kuesioner, kemudian digunakan metode kualitatif berupa pemetaan ruang terbuka eksisting dan ruang terbuka potensial, deskripsi hasil identifikasi dan perhitungan, serta interpretasi hasil kuesioner.

\subsection{Metode Pengumpulan Data}

Metode pengumpulan data yang digunakan pada penelitian ini terdiri dari data primer dan sekunder. Data primer merupakan data yang diperoleh secara langsung dengan tujuan untuk melihat keadaan objek penelitian apa adanya. Data sekunder adalah data yang didapat melalui media perantara atau diperoleh dan dicatat oleh pihak lain berupa buku, catatan, atau arsip baik yang dipublikasikan maupun yang tidak dipublikasikan secara umum.

Instrumen pengumpulan data yang digunakan adalah observasi, wawancara, dan kuesioner. Observasi yaitu pengamatan secara langsung pada objek penelitian untuk melihat objek tersebut secara langsung dan nyata [8]. Observasi dilakukan di Kampus Itenas dengan melakukan pengamatan pada atribut green open space berupa jumlah dan jenis tanaman. Wawancara adalah pengumpulan data dan informasi melalui sumbernya langsung di mana pewawancara memberikan pertanyaan dan responden memberikan 
jawabannya [8]. Wawancara dilakukan kepada PT. ISS untuk mengetahui jumlah kendaraan bermotor. Kuesioner yaitu daftar pertanyaan untuk mendapat tanggapan dari responden terkait topik yang diinginkan oleh peneliti [8]. Penyebaran kuesioner dilakukan untuk mengetahui pengetahuan, kepedulian, serta bentuk peran aktif civitas akademika terkait atribut green open space.

Penyebaran kuesioner menggunakan metode probability sampling, yaitu peneliti menentukan sampel secara acak di mana anggota populasi memiliki peluang yang sama untuk menjadi anggota sampel [7]. Teknik yang digunakan adalah proportionate stratified random sampling di mana sampel dipilih secara proporsional [7] dan populasi terdiri dari anggota yang heterogen berdasarkan tingkatan jabatan. Tingkatan yang dimaksud adalah civitas akademika yang terdiri dari mahasiswa dan dosen tetap dari semua jurusan, serta tenaga kependidikan dan non kependidikan.

Sampel ditentukan melalui jumlah populasi yang telah diketahui dibagi secara proporsional yang dianggap dapat mewakili seluruh civitas akademika. Populasi civitas akademika di Kampus Itenas adalah 7.377 orang dengan rincian 6.889 orang mahasiswa, 244 orang dosen tetap, dan 244 orang tenaga kependidikan dan non kependidikan. Jumlah sampel dari penyebaran kuesioner ini adalah 129 orang dengan rincian 101 mahasiswa, 13 dosen, serta 15 tenaga kependidikan dan non kependidikan. Penentuan sampel untuk mahasiswa didasarkan pada proporsi jumlah mahasiswa per jurusan dibandingkan dengan jumlah keseluruhan (total). Sedangkan penentuan sampel untuk dosen tetap dari semua jurusan, serta tenaga kependidikan dan non kependidikan didasarkan pada angka proporsional yang dapat mewakili populasi yaitu 1 orang.

\subsection{Metode Analisis}

Metode analisis yang digunakan untuk data kuantitatif adalah distribusi frekuensi dan scoring. Distribusi frekuensi yaitu penyajian data dalam bentuk tabel dengan membagi data-data tersebut ke dalam beberapa kelas atau kategori. Scoring adalah proses pengubahan suatu data kualitatif menjadi data kuantitatif berupa angka-angka. Metode yang digunakan untuk data kualitatif adalah metode komparatif, yaitu membandingkan data eksisting hasil observasi dengan standar yang berlaku.

Kebutuhan ruang terbuka hijau dapat dihitung berdasarkan kebutuhan oksigen melalui Metode Gerarkis dalam Wisesa yang dikembangkan oleh Wijayanti [9] dan tercantum pada Peraturan Menteri Pekerjaan Umum Nomor : 05/PRT/M/2008 [2], dengan rumus [9]:

$\mathrm{L}_{\mathrm{t}}=\frac{\mathrm{X}_{\mathrm{t}}+\mathrm{Y}_{\mathrm{t}}}{(54)(0,9375)(2)} \mathrm{m}^{2} \quad \mathrm{~L}_{\mathrm{t}}=\frac{\mathrm{P}_{\mathrm{t}}+\mathrm{K}_{\mathrm{t}}+\mathrm{T}_{\mathrm{t}}}{(54)(0,9375)(2)} \mathrm{m}^{2}$

Keterangan:

Lt : Luas RTH Kota pada tahun ke $\mathrm{t}\left(\mathrm{m}^{2}\right)$

$\mathrm{X}_{\mathrm{t}} / \mathrm{P}_{\mathrm{t}}$ : Jumlah kebutuhan oksigen bagi penduduk pada tahun ke $\mathrm{t}$ (gram/hari)

$\mathrm{Y}_{\mathrm{t}} / \mathrm{K}_{\mathrm{t}}$ : Jumlah kebutuhan oksigen bagi kendaraan bermotor pada tahun ke $\mathrm{t}$ (gram/hari)

$\mathrm{T}_{\mathrm{t}} \quad$ : Jumlah kebutuhan oksigen bagi ternak pada tahun ke $\mathrm{t}$ (gram/hari)

54 : Konstanta yang menunjukkan bahwa $1 \mathrm{~m}^{2}$ luas lahan menghasilkan 54 gram berat kering tanaman per hari (gram $/$ hari $/ \mathrm{m}^{2}$ )

0,9375 : Konstanta yang menunjukkan bahwa 1 gram berat kering tanaman setara dengan produksi oksigen sebesar 0,9375 gram (gram/hari)

2 : Jumlah musim di Indonesia 
Manusia membutuhkan 600 liter $\mathrm{O}_{2}$ setiap hari atau setara dengan $0,864 \mathrm{~kg} \mathrm{O}_{2}$ per hari atau 864 gram $\mathrm{O}_{2}$ per hari, sehingga perhitungan dilakukan melalui perkalian antara jumlah populasi kampus dengan standar kebutuhan oksigen per hari. Kendaraan bermotor memiliki standar kebutuhan oksigen yang dapat dilihat pada Tabel 2. di mana perhitungannya disesuaikan dengan asumsi waktu penggunaan kendaraan bermotor per hari (dalam jam). Konsumsi oksigen untuk hewan ternak tidak akan dijabarkan dalam penelitian ini karena pada area kampus tidak terdapat hewan ternak.

Tabel 2. Kebutuhan Oksigen Berdasarkan Jenis Kendaraan Bermotor [9]

\begin{tabular}{|c|c|c|c|c|c|c|}
\hline \multirow[t]{3}{*}{ Jenis Kendaraan } & \multirow[t]{3}{*}{$\begin{array}{l}\text { Bahan } \\
\text { Bakar }\end{array}$} & $\begin{array}{c}\text { Kebutuhan } \\
\text { Bahan } \\
\text { Bakar } \\
\text { (kg/PS.jam) }\end{array}$ & $\begin{array}{c}\text { Daya } \\
\text { (PS) }\end{array}$ & $\begin{array}{c}\text { Kebutuhan } \\
\text { O}_{2} \text { per } 1 \text { kg } \\
\text { Bahan Bakar } \\
\text { (kg) }\end{array}$ & $\begin{array}{c}\text { Kebutuhan } \\
\mathrm{O}_{2} \\
\text { (kg/jam) }\end{array}$ & $\begin{array}{c}\text { Kebutuhan } \\
\mathrm{O}_{2} \\
\text { (gram/jam) }\end{array}$ \\
\hline & & \multirow[b]{2}{*}{$\mathbf{A}$} & \multirow[b]{2}{*}{$\mathbf{B}$} & \multirow[b]{2}{*}{$\mathbf{C}$} & D & $\mathbf{E}$ \\
\hline & & & & & $\mathrm{A} \times \mathrm{B} \times \frac{\mathrm{C}}{1 \mathrm{~kg}}$ & $\mathrm{D} \times 1.000$ \\
\hline Sepeda Motor & Bensin & 0,21 & 1 & 2,77 & 0,58 & 580 \\
\hline Kendaraan Penumpang & Bensin & 0,21 & 20 & 2,77 & 11,63 & 11.630 \\
\hline Kendaraan Beban & Diesel & 0,16 & 50 & 2,86 & 22,88 & 22.880 \\
\hline Bis & Diesel & 0,16 & 100 & 2,86 & 45,76 & 45.760 \\
\hline
\end{tabular}

Kebutuhan jumlah pohon dihitung berdasarkan 1 batang pohon dapat menghasilkan oksigen sebesar 875 liter per hari atau setara dengan 1,26 kg per hari atau setara dengan 1.260 gram per hari [9] yang dapat dihitung menggunakan rumus:

Kebutuhan Jumlah Pohon $(\mathrm{KP})=\frac{\text { Kebutuhan } \mathrm{O}_{2} \text { Manusia }}{\text { Produksi } \mathrm{O}_{2} \text { Pohon }}$ gram $/$ hari

Selain itu, terdapat standar atribut green open space dari kategori penataan dan infrastruktur berdasarkan UI GreenMetric World University Rankings 2018 yang juga ditentukan parameter dan angka penilaian (rentang interval) berdasarkan Peraturan Daerah Kota Bandung Nomor 5 Tahun 2010 Tentang Bangunan Gedung [10], Peraturan Menteri Pekerjaan Umum Nomor: 12/PRT/M/2009 Tentang Pedoman Penyediaan dan Pemanfaatan Ruang Terbuka Non Hijau di Wilayah Kota/Kawasan Perkotaan [11], serta Perhitungan Kebutuhan Jumlah Pohon dan Metode Gerarkis dalam Wisesa yang dikembangkan oleh Wijayanti [9] dan ditunjukkan pada Tabel 3. 
Tabel 3. Penjelasan Indikator Kategori Penataan dan Infrastruktur pada UI Greenmetric World University Rankings 2018

\begin{tabular}{|c|c|c|c|}
\hline No. & Indikator & Parameter & Penjelasan \\
\hline S 1 & $\begin{array}{l}\text { Perbandingan antara } \\
\text { ruang terbuka } \\
\text { dengan total area }\end{array}$ & $\begin{array}{l}\text { a. KDB tinggi }(>60 \%- \\
100 \%) \\
\text { b. KDB sedang }(30 \%- \\
60 \%) \\
\text { c. KDB rendah }(<30 \%) \\
\text { Luas ruang terbuka hijau } \\
\text { adalah } 40 \% \text { dari luas } \\
\text { wilayah kampus } \\
\text { Sumber: Peraturan Daerah } \\
\text { Kota Bandung Nomor } 5 \\
\text { Tahun 2010 Tentang } \\
\text { Bangunan Gedung }\end{array}$ & $\begin{array}{l}\text { Dihitung melalui persentase luas ruang terbuka } \\
\text { dibandingkan dengan luas keseluruhan kampus, } \\
\text { di mana KDB yang dijadikan standar adalah } \\
\text { KDB sedang sebesar } 60 \% \text {, sehingga standar luas } \\
\text { ruang terbuka hijau adalah } 40 \% \text { dari luas wilayah } \\
\text { kampus. Angka penilaian tertinggi yang } \\
\text { digunakan mengacu pada KDB rendah yaitu } \\
\text { 30\%, sehingga luas ruang terbuka hijau tertinggi } \\
\text { adalah } 70 \% \text { dari luas wilayah kampus. }\end{array}$ \\
\hline S 2 & $\begin{array}{c}\text { Persentase area } \\
\text { kampus yang berupa } \\
\text { hutan }\end{array}$ & $\begin{array}{l}\text { Sumber: Peraturan Menteri } \\
\text { Pekerjaan Umum Nomor: } \\
\text { 12/PRT/M/2009 Tentang } \\
\text { Pedoman Penyediaan dan } \\
\text { Pemanfaatan Ruang } \\
\text { Terbuka Non Hijau di } \\
\text { Wilayah Kota/Kawasan } \\
\text { Perkotaan }\end{array}$ & $\begin{array}{l}\text { Dihitung melalui persentase area kampus yang } \\
\text { berupa hutan, di mana perhitungannya dilakukan } \\
\text { melalui penyediaan ruang terbuka pada bangunan } \\
\text { pendidikan (SMU) disesuaikan dengan luas RTH } \\
\text { dan RTNH disesuaikan dengan Koefisien Dasar } \\
\text { Hijau (KDH) suatu lahan. } \\
\text { Poin pada indikator ini adalah } 300 \text { yang terdiri } \\
\text { dari } 11 \text { kelas dengan rentang poin } 30 \text { untuk setiap } \\
\text { kelas. Rentang interval ditentukan melalui } \\
\text { 18,52\% dibagi dengan jumlah kelas yang } \\
\text { memiliki interval yaitu 9, sehingga diperoleh } \\
\text { interval sebesar } 2,06 \% \text {. }\end{array}$ \\
\hline S 3 & $\begin{array}{c}\text { Persentase area } \\
\text { kampus yang } \\
\text { ditutupi dengan } \\
\text { tanaman/taman } \\
\text { (termasuk rumput, } \\
\text { kebun, dan lain-lain) }\end{array}$ & $\begin{array}{l}\text { Persentase area } \\
\text { yang ditutupi } \begin{array}{r}\text { kampus } \\
\text { dengan }\end{array} \\
\text { tanaman/ taman } \\
\text { adalah } \\
\text { 18,52\%, yang lebih } \\
\text { jelasnya dapat dilihat pada } \\
\text { Tabel 4. } \\
\text { Sumber: Peraturan Menteri } \\
\text { Pekerjaan Umum Nomor: } \\
\text { 12/PRT/M/2009 Tentang } \\
\text { Pedoman Penyediaan dan } \\
\text { Pemanfaatan Ruang } \\
\text { Terbuka Non Hijau di } \\
\text { Wilayah Kota/Kawasan } \\
\text { Perkotaan }\end{array}$ & $\begin{array}{l}\text { Dihitung melalui persentase area kampus yang } \\
\text { ditutupi dengan tanaman/taman, di mana } \\
\text { perhitungannya dilakukan melalui penyediaan } \\
\text { ruang terbuka pada bangunan pendidikan (SMU) } \\
\text { disesuaikan dengan luas RTH dan RTNH } \\
\text { disesuaikan dengan Koefisien Dasar Hijau } \\
\text { (KDH) suatu lahan. } \\
\text { Poin pada indikator ini adalah } 200 \text { yang terdiri } \\
\text { dari } 11 \text { kelas dengan rentang poin } 20 \text { untuk setiap } \\
\text { kelas. Rentang interval ditentukan melalui } \\
\text { 18,52\% dibagi dengan jumlah kelas yang } \\
\text { memiliki interval yaitu 9, sehingga diperoleh } \\
\text { interval sebesar } 2,06 \% \text {. }\end{array}$ \\
\hline
\end{tabular}




\begin{tabular}{|c|c|c|c|}
\hline No. & Indikator & Parameter & Penjelasan \\
\hline S 4 & $\begin{array}{c}\text { Persentase area } \\
\text { permukaan di } \\
\text { lingkungan kampus } \\
\text { yang dapat menyerap } \\
\text { air (termasuk tanah } \\
\text { atau con-block) }\end{array}$ & $\begin{array}{l}\text { Luas permukaan yang dapat } \\
\text { menyerap air adalah } 40 \% \\
\text { dari luas wilayah kampus } \\
\text { Sumber: Peraturan Daerah } \\
\text { Kota Bandung Nomor } 5 \\
\text { Tahun } 2010 \text { Tentang } \\
\text { Bangunan Gedung }\end{array}$ & $\begin{array}{l}\text { Dihitung melalui persentase area permukaan } \\
\text { yang dapat menyerap air, di mana KDB yang } \\
\text { dijadikan standar adalah KDB sedang sebesar } \\
60 \% \text {, sehingga standar luas ruang terbuka hijau } \\
\text { adalah } 40 \% \text { dari luas wilayah kampus. Angka } \\
\text { penilaian tertinggi yang digunakan mengacu } \\
\text { pada KDB rendah yaitu } 30 \% \text {, sehingga luas ruang } \\
\text { terbuka hijau tertinggi adalah } 70 \% \text { dari luas } \\
\text { wilayah kampus. } \\
\text { Poin untuk indikator ini adalah } 300 \text { yang terdiri } \\
\text { dari } 11 \text { kelas dengan rentang poin } 30 \text { untuk setiap } \\
\text { kelas. Rentang interval ditentukan melalui } 70 \% \\
\text { dibagi dengan jumlah kelas yang memiliki } \\
\text { interval yaitu 9, sehingga diperoleh interval } \\
\text { sebesar } 7,78 \% \text {. }\end{array}$ \\
\hline S 5 & $\begin{array}{l}\text { Total ruang terbuka } \\
\text { dibagi dengan } \\
\text { populasi kampus }\end{array}$ & $\begin{array}{l}\text { Sumber: Peraturan Menteri } \\
\text { Pekerjaan Umum Nomor: } \\
\text { 12/PRT/M/2009 Tentang } \\
\text { Pedoman Penyediaan dan } \\
\text { Pemanfaatan Ruang } \\
\text { Terbuka Non Hijau di } \\
\text { Wilayah Kota/Kawasan } \\
\text { Perkotaan }\end{array}$ & $\begin{array}{l}\text { Dihitung melalui luas ruang } \\
\text { dibandingkan dengan populasi kampus, di mana } \\
\text { perhitungannya mengacu pada standar } \\
\text { penyediaan ruang terbuka pada bangunan } \\
\text { pendidikan (SMU) sebesar } 2,6 \mathrm{~m}^{2} \text { per jiwa untuk } \\
4.800 \text { penduduk pendukung atau setara dengan } \\
0,000542 \mathrm{~m}^{2} \text { per jiwa. Populasi Kampus Itenas } \\
\text { adalah } 7.377 \text { jiwa sehingga diperoleh standar } \\
\text { penyediaan ruang terbuka sebesar } 4 \mathrm{~m}^{2} \text { per jiwa. }\end{array}$ \\
\hline
\end{tabular}

Perhitungan untuk mengetahui persentase luas RTH dan RTNH dapat dilihat pada Tabel 4 berikut.

Tabel 4. Perhitungan Persentase Standar Luas RTH dan RTNH

\begin{tabular}{|c|c|c|c|c|c|c|}
\hline \multirow{3}{*}{$\begin{array}{c}\text { Jumlah } \\
\text { Populasi } \\
\text { Kampus (Jiwa) }\end{array}$} & \multicolumn{2}{|c|}{ Kebutuhan per Satuan } & \multirow{3}{*}{$\begin{array}{c}\text { Standar } \\
\left(\mathrm{m}^{2} / \mathrm{jiwa}\right. \\
)\end{array}$} & \multirow{3}{*}{$\begin{array}{c}\text { Luas RT } \\
\quad\left(\mathbf{m}^{2}\right)\end{array}$} & \multirow{3}{*}{$\begin{array}{c}\text { Luas RTH } \\
\left(\mathbf{m}^{2}\right)\end{array}$} & \multirow{3}{*}{$\begin{array}{c}\text { Luas RTNH } \\
\qquad\left(\mathbf{m}^{2}\right)\end{array}$} \\
\hline & SaI & ana & & & & \\
\hline & $\begin{array}{c}\text { Luas Lantai } \\
\text { Minimal } \\
\left(\mathbf{m}^{2}\right) \\
\end{array}$ & $\begin{array}{c}\text { Luas Lahan } \\
\text { Minimal } \\
\left(\mathbf{m}^{2}\right) \\
\end{array}$ & & & & \\
\hline \multirow[b]{2}{*}{$\mathbf{A}$} & B & $\mathbf{C}$ & \multirow[b]{2}{*}{$\mathbf{D}^{* *}$} & $\mathbf{E}$ & $\mathbf{F}$ & $\mathbf{G}$ \\
\hline & $\mathrm{A} \times 0,80^{*}$ & $\mathrm{~A} \times \mathrm{D}$ & & $\mathrm{C}-\mathrm{B}$ & $\mathrm{KDH}^{* * *} \times \mathrm{E}$ & $\begin{array}{c}(100 \%-\mathrm{KDH}) \\
\times \mathrm{E}\end{array}$ \\
\hline 7.377 & $5.893,92$ & $29.477,57$ & 4,00 & $\begin{array}{c}23.583,6 \\
5\end{array}$ & $\begin{array}{c}9.805,11 \\
(18,52 \%)^{* * * * *}\end{array}$ & $\begin{array}{c}13.778,54 \\
(21,48 \%) * * * * *\end{array}$ \\
\hline
\end{tabular}




\section{Potensi Penerapan Konsep Green Campus pada Atribut Green Open Space \\ di Institut Teknologi Nasional (Itenas) Bandung}

Keterangan:

* : : Standar luas lantai minimal per $\mathrm{m}^{2}$

** : Standar ruang terbuka adalah $0,000542 \mathrm{~m}^{2}$ per jiwa, dikalikan dengan jumlah penduduk yaitu 7.377 jiwa

*** : Pembagian antara luas ruang terbuka hijau eksisting yaitu $8.395 \mathrm{~m}^{2}$ dengan luas ruang terbuka yaitu $20.192 \mathrm{~m}^{2}=41,58 \%$

**** : Pembagian antara luas ruang terbuka hijau hasil perhitungan yaitu 9.805,11 $\mathrm{m}^{2}$ dengan luas lahan yaitu $52.954 \mathrm{~m}^{2}$

***** : Standar ruang terbuka sebesar 40\% dikurangi dengan persentase $\mathrm{KDH}$

Potensi penerapan konsep green campus pada atribut green open space dapat diketahui melalui observasi dan survei sekunder untuk menentukan lokasi potensial beserta luasannya yang dapat dibangun ruang terbuka hijau, khususnya taman. Setelah itu, ketersediaan atau potensi lahan tersebut dibandingkan dengan kebutuhan ruang terbuka hijau dan potensi civitas akademika berdasarkan hasil penyebaran kuesioner sehingga diketahui selisih potensi lahan dengan kebutuhan civitas akademika. Pada lokasi potensial tersebut, akan dilakukan perhitungan jumlah tegakan yang dapat ditanam pada lokasi potensial. Jumlah tegakan pada lokasi potensial disesuaikan dengan luas lahan, jenis tanaman, dan jarak tanam, yang dapat dihitung menggunakan rumus [12] berikut.

Jumlah Tegakan $=\frac{\text { Luas Lahan }}{\text { Jarak Tanam }}$

Hasil dari perhitungan jumlah tegakan tersebut selanjutnya dapat digunakan untuk memperkirakan produksi oksigen (1.260 gram per hari) yang dihasilkan oleh tanaman tambahan yang ditanam dan jumlah populasi kampus yang dapat dipenuhi kebutuhan oksigennya (864 gram per hari) oleh tanaman tambahan yang ditanam. Selain melakukan perhitungan lokasi potensial bagi peningkatan ruang terbuka hijau berupa tanaman dan taman, dilakukan observasi dan survei sekunder untuk menentukan lokasi potensial yang dapat dibangun vertical garden dan roof garden. Hal tersebut dilakukan untuk memanfaatkan lahan kosong di Itenas secara optimal.

\section{HASIL PENELITIAN DAN PEMBAHASAN}

\subsection{Gambaran Umum Institut Teknologi Nasional (Itenas)}

Institut Teknologi Nasional (Itenas) merupakan perguruan tinggi swasta yang terletak di Jalan PHH. Mustofa No. 23, Kelurahan Neglasari, Kecamatan Cibeunying Kaler, Kota Bandung. Batas administratif Kampus Itenas adalah sebagai berikut.

- Bagian Utara : Gedung Balai Pelatihan Pendidik dan Tenaga Kependidikan Pendidikan Kejuruan, serta permukiman warga

- Bagian Selatan : Jalan PHH. Mustofa

- Bagian Barat : Jalan Pahlawan

- Bagian Timur : Kampus STIE Ekuitas dan permukiman warga

Berdasarkan hasil perhitungan menggunakan aplikasi AutoCAD, berikut rincian luas guna lahan di Itenas. 
Tabel 5. Jenis dan Luas Guna Lahan di Itenas

\begin{tabular}{|c|c|c|c|c|c|c|}
\hline No. & Jenis Guna Lahan & & Luas & $\left.n^{2}\right)$ & Persen & ase \\
\hline 1 & Bangunan & & 32. & & 61,8 & \\
\hline 2 & Ruang Terbuka Hijau & \multirow{3}{*}{$\begin{array}{l}\text { Ruang } \\
\text { Terbuka }\end{array}$} & 8.395 & \multirow{3}{*}{20.192} & $15,85 \%$ & \multirow{3}{*}{$38,13 \%$} \\
\hline 3 & $\begin{array}{c}\text { Lahan Parkir, Jalan, dan Lahan } \\
\text { Kosong }\end{array}$ & & 11.648 & & $22,00 \%$ & \\
\hline 4 & Jalur Pedestrian & & 149 & & $0,28 \%$ & \\
\hline & TOTAL & & \multicolumn{2}{|c|}{52.954} & \multicolumn{2}{|c|}{$100 \%$} \\
\hline
\end{tabular}

Populasi civitas akademika di Kampus Itenas adalah 7.377 orang dengan rincian 6.889 orang mahasiswa, 244 orang dosen tetap, dan 244 orang tenaga kependidikan dan non kependidikan, yang dapat dilihat pada tabel berikut.

Tabel 6. Jumlah Mahasiswa, Dosen Tetap, Tenaga Kependidikan, dan Tenaga Non Kependidikan di Itenas Tahun 2018

\begin{tabular}{|c|c|c|c|c|}
\hline Kode & Program Studi / Unit Kerja & $\begin{array}{c}\text { Jumlah } \\
\text { Mahasiswa }\end{array}$ & $\begin{array}{c}\text { Jumlah } \\
\text { Dosen Tetap }\end{array}$ & $\begin{array}{c}\text { Jumlah Tenaga } \\
\text { Kependidikan dan } \\
\text { Non Kependidikan }\end{array}$ \\
\hline \multicolumn{4}{|c|}{ Fakultas Teknologi Industri (FTI) } & 10 \\
\hline 11 & Teknik Elektro & 370 & 19 & 5 \\
\hline 12 & Teknik Mesin & 593 & 25 & 8 \\
\hline 13 & Teknik Industri & 851 & 30 & 3 \\
\hline 14 & Teknik Kimia & 273 & 16 & 4 \\
\hline 15 & Teknik Informatika & 485 & 20 & 4 \\
\hline 16 & Sistem Informasi & 45 & - & - \\
\hline \multicolumn{4}{|c|}{ Fakultas Teknik Sipil dan Perencanaan (FTSP) } & 13 \\
\hline 21 & Arsitektur & 807 & 22 & 5 \\
\hline 22 & Teknik Sipil & 1.037 & 27 & 8 \\
\hline 23 & Teknik Geodesi & 455 & 16 & 3 \\
\hline 24 & Perencanaan Wilayah dan Kota & 483 & 13 & 2 \\
\hline 25 & Teknik Lingkungan & 474 & 16 & 5 \\
\hline \multicolumn{4}{|c|}{ Fakultas Seni Rupa dan Desain (FSRD) } & 7 \\
\hline 31 & Desain Interior & 512 & 15 & 2 \\
\hline 32 & Desain Produk & 112 & 9 & 2 \\
\hline 33 & Desain Komunikasi Visual & 392 & 16 & 1 \\
\hline \multirow{10}{*}{$\begin{array}{l}\text { Unit } \\
\text { Kerja }\end{array}$} & YPDS (4 sub unit) & & & 20 \\
\hline & Rektorat (9 sub unit) & & & 56 \\
\hline & Satpam & & & 16 \\
\hline & Supir & & & 2 \\
\hline & Petugas Gedung & & & 49 \\
\hline & Petugas Kebun & & & 1 \\
\hline & UPT Perpustakaan & & & 8 \\
\hline & UPT TIK & & & 5 \\
\hline & UPT PK & & & 2 \\
\hline & LPPM & & & 3 \\
\hline & TOTAL & 6.889 & 244 & 244 \\
\hline
\end{tabular}




\subsection{Identifikasi Kondisi Eksisting pada Atribut Green Open Space di Institut Teknologi Nasional (Itenas)}

Kondisi atribut green open space di Kampus Itenas dapat diketahui melalui pengamatan tanaman pada halaman bangunan, tanaman pada pot, tanaman pada dinding atau secara vertikal, dan tanaman pada atap bangunan. Pengamatan dilakukan untuk mengetahui jenis, jumlah, dan fungsi masing-masing tanaman yang akan disesuaikan dengan kebutuhan ruang terbuka hijau dan kebutuhan jumlah pohon untuk Kampus Itenas.

Berdasarkan observasi yang telah dilakukan, dapat diketahui bahwa Institut Teknologi Nasional (Itenas) memiliki 539 tanaman pada taman, 309 tanaman pada pot, dan 8 tanaman pada dinding atau secara vertikal dengan jumlah keseluruhan 856 tanaman. Lapangan tenis dan cafetaria merupakan gedung dengan jumlah tanaman pada taman terbanyak yaitu masing-masing 87 dan 63 batang pohon karena pohon (khususnya cemara pua-pua) ditanam secara berhimpitan dengan jumlah yang banyak.

Jenis tanaman pada halaman bangunan yang banyak tumbuh di Itenas adalah cemara pua-pua sebanyak 84 pohon, pinus merkusii sebanyak 42 pohon, dan pohon dari suku pinang-pinangan atau palem. Sedangkan tanaman pada pot didominasi oleh jenis tanaman palem putri sebanyak 24 pot dan sri rejeki sebanyak 18 pot. Jenis tanaman yang banyak tumbuh di Itenas adalah tanaman dengan fungsi sebagai reduktor polutan dan sebagai peneduh di mana tanaman-tanaman tersebut didominasi oleh tanaman hias.

\subsection{Identifikasi Karakteristik Civitas Akademika Institut Teknologi Nasional (Itenas)}

Jumlah sampel dari penyebaran kuesioner adalah 129 orang dengan rincian 101 mahasiswa, 13 dosen, serta 15 tenaga kependidikan dan non kependidikan. Karakteristik civitas akademika Institut Teknologi Nasional (Itenas) berdasarkan hasil kuesioner terdiri dari umur, jenis kelamin, dan angkatan.

Umur responden dikelompokkan menjadi 6 kategori yaitu 20, 21, 22, 23, 24, dan lebih dari 25 tahun. Responden didominasi oleh civitas akademika yang berumur 21 tahun. Lebih jelasnya, dapat dilihat pada pie chart pada Gambar 1 berikut.

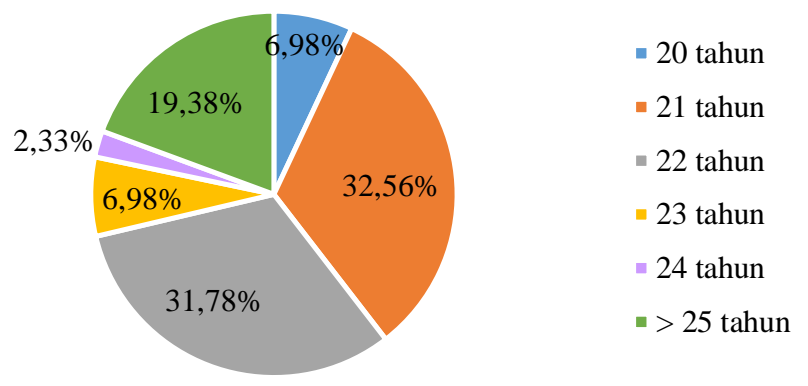

\section{Gambar 1. Pie Chart Responden Berdasarkan Umur di Itenas}

Jenis kelamin responden terdiri dari perempuan dan laki-laki. Responden didominasi oleh civitas akademika dengan jenis kelamin laki-laki, yang lebih jelasnya dapat dilihat pada pie chart pada Gambar 2 berikut. 


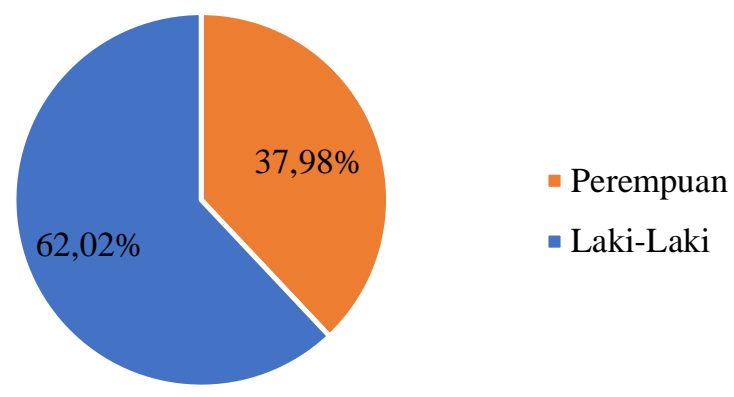

\section{Gambar 2. Pie Chart Responden Berdasarkan Jenis Kelamin di Itenas}

Responden terdiri dari mahasiswa angkatan 2014, 2015, dan 2016, serta pegawai pada unit kerja yang termasuk pada kelompok tanpa angkatan. Responden didominasi oleh mahasiswa dari angkatan 2015, yang lebih jelasnya dapat dilihat pada pie chart pada Gambar 3 berikut.

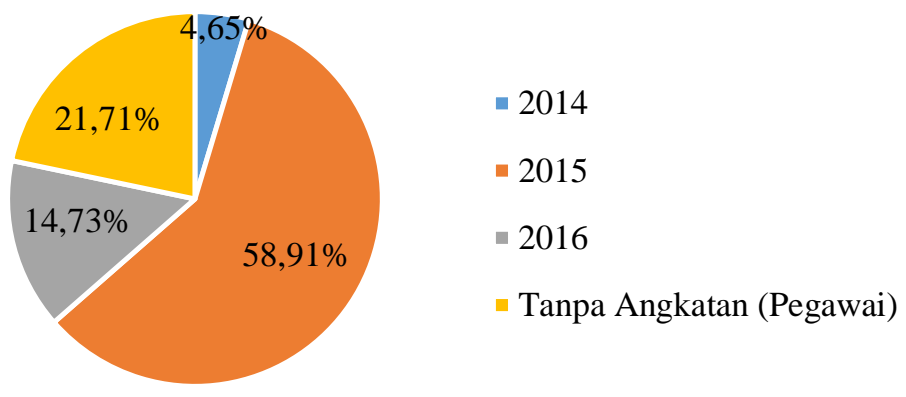

Gambar 3. Pie Chart Responden Berdasarkan Angkatan di Itenas

\subsection{Identifikasi Kebutuhan pada Atribut Green Open Space}

Kebutuhan ruang terbuka hijau dapat dihitung berdasarkan kebutuhan oksigen melalui Metode Gerarkis dalam Wisesa yang dikembangkan oleh Wijayanti [9] dan tercantum pada Peraturan Menteri Pekerjaan Umum Nomor : 05/PRT/M/2008 [2].

Sebagian civitas akademika Itenas menggunakan kendaraan bermotor pribadi untuk menuju kampus, yakni berupa sepeda motor atau kendaraan penumpang (mobil). Sepeda motor memiliki kebutuhan oksigen sebesar 580 gram oksigen per jam dan kendaraan penumpang berupa mobil memiliki kebutuhan oksigen sebesar 11.630 gram oksigen per jam di mana asumsi rata-rata penggunaan kendaraan bermotor tersebut adalah 10 menit atau 0,17 jam per hari karena kendaraan hanya diparkirkan dan tidak digunakan untuk lalu lalang di dalam Kampus Itenas. Rata-rata penggunaan kendaraan bermotor tersebut diasumsikan bahwa civitas akademika membutuhkan 10 menit untuk mencari parkir dan keluar parkir. Rata-rata jumlah sepeda motor yang parkir di Kampus Itenas adalah 60.196 unit dan mobil sebanyak 10.687 unit.

Berdasarkan perhitungan yang telah dilakukan, diperoleh kebutuhan ruang terbuka hijau seluas $325.013,76 \mathrm{~m}^{2}$. Jika dibandingkan dengan luas eksisting ruang terbuka hijau pada Kampus Itenas seluas $8.395 \mathrm{~m}^{2}$, maka luasan ruang terbuka hijau jauh dari kata memadai. Kebutuhan jumlah pohon dihitung berdasarkan kebutuhan oksigen penduduk dibandingkan dengan 1 batang pohon dapat menghasilkan oksigen sebesar 875 liter per hari atau setara dengan 1,26 kg per hari atau setara dengan 1.260 gram per hari [9]. Berdasarkan perhitungan yang telah dilakukan, diperoleh kebutuhan pohon pada Kampus Itenas sebanyak 5.059 batang. Jika dibandingkan dengan jumlah eksisting pohon pada Kampus Itenas sebanyak 539 batang, maka jumlah pohon di Itenas jauh dari kata memadai karena terdapat selisih sebesar 4.520 batang pohon. 


\subsection{Potensi Penerapan Konsep Green Campus pada Atribut Green Open Space di Institut Teknologi Nasional (Itenas)}

Potensi penerapan konsep green campus pada atribut green open space di Itenas dapat diketahui melalui perbandingan antara kebutuhan ruang terbuka hijau dan potensi civitas akademika berdasarkan hasil penyebaran kuesioner dengan ketersediaan lahan bagi peningkatan jumlah tanaman dan taman di Itenas. Berdasarkan hal tersebut, dapat dilihat analisis kebutuhan lahan dan potensi civitas akademika dibandingkan dengan potensi lahan ruang terbuka hijau pada Tabel 7 berikut.

Tabel 7. Analisis Kebutuhan Lahan dan Potensi Civitas Akademika dibandingkan dengan Potensi Lahan Ruang Terbuka Hijau di Itenas

\begin{tabular}{|c|c|c|c|c|}
\hline \multirow{3}{*}{ Lokasi Potensial } & $\begin{array}{c}\text { Luas } \\
\text { Lahan }\left(\mathbf{m}^{2}\right)\end{array}$ & $\begin{array}{c}\text { Luas } \\
\text { Kebutuhan } \\
\text { Lahan }\left(\mathbf{m}^{2}\right)\end{array}$ & $\begin{array}{c}\text { Selisih Potensi } \\
\text { Lahan dengan } \\
\text { Kebutuhan }\end{array}$ & \multirow{3}{*}{$\begin{array}{c}\text { Potensi Civitas } \\
\text { Akademika }\end{array}$} \\
\hline & \multirow{2}{*}{$\mathbf{A}$} & \multirow{2}{*}{ B } & $\mathrm{C}$ & \\
\hline & & & $\mathrm{B}-\mathrm{A}$ & \\
\hline Lapangan Tenis & $1.533,71$ & \multirow{6}{*}{$9.295,02 \mathrm{~m}^{2}$} & \multirow{6}{*}{$4.641,16 \mathrm{~m}^{2}$} & \multirow{4}{*}{$\begin{array}{l}\text { a. Memiliki pengetahuan } \\
\text { yang tinggi } \\
\text { b. Memiliki kepedulian } \\
\text { yang sangat tinggi } \\
\text { c. Memiliki peran aktif } \\
\text { yang sangat tinggi }\end{array}$} \\
\hline Sekitar gedung serba guna & 116,61 & & & \\
\hline $\begin{array}{c}\text { Sekitar gedung } 2,3 \text {, dan } \\
21\end{array}$ & $1.453,88$ & & & \\
\hline Sekitar gedung 5 dan 6 & 698,04 & & & \\
\hline Student Center & 851,62 & & & \multirow{2}{*}{$\begin{array}{l}\text { Rekomendasi: } \\
\text { Penyediaan RTH di seluruh } \\
\text { area kampus dan student } \\
\text { center }\end{array}$} \\
\hline Total & $4.653,86$ & & & \\
\hline
\end{tabular}

Berdasarkan hasil observasi yang telah dilakukan, dapat diketahui beberapa lokasi potensial berupa lahan kosong yang tidak dimanfaatkan secara optimal sehingga pada lokasi tersebut dapat dibangun taman untuk meningkatkan penyediaan ruang terbuka hijau di Itenas. Lapangan tenis termasuk pada lokasi potensial karena beberapa responden beranggapan bahwa lokasi tersebut kurang memberikan manfaat bagi civitas akademika dan pada lokasi tersebut terasa panas dan gersang sehingga perlu dilakukan perubahan fungsi lahan menjadi ruang terbuka hijau.

Kampus Itenas memiliki lima lokasi potensial berupa lahan kosong untuk dijadikan taman, di mana pada masing-masing lokasi potensial tersebut dapat dihitung jumlah tegakan (pohon) yang dapat ditanam. Jumlah tegakan yang dapat ditanam pada lokasi potensial di Itenas dapat dilihat pada Tabel 8 berikut.

Tabel 8. Jumlah Tegakan pada Lokasi Potensial di Itenas

\begin{tabular}{ccccc}
\hline & & Luas Lahan $\left(\mathbf{m}^{\mathbf{2}}\right)$ & Jarak Tanam & $\begin{array}{c}\text { Jumlah Tegakan } \\
\text { (batang pohon) }\end{array}$ \\
\cline { 3 - 5 } & Lokasi Potensial & $\mathbf{A}$ & B & C \\
\cline { 3 - 5 } & & $1.533,71$ & $2 \times 2$ meter & 383 \\
\hline 1 & Lapangan Tenis & 116,61 & $1 \times 1$ meter & 117 \\
\hline 3 & Sekitar gedung serba guna & $1.453,88$ & $2 \times 2$ meter & 363 \\
\hline 4 & Sekitar gedung 2, 3, dan 21 & 698,04 & $2 \times 2$ meter & 175 \\
\hline 5 & Sekitar gedung 5 dan 6 & 851,62 & $2 \times 2$ meter & 213 \\
\hline & Student Center & $\mathbf{4 . 6 5 3 , 8 6}$ & & $\mathbf{1 . 2 5 1}$
\end{tabular}


Berdasarkan perhitungan jumlah tegakan, dapat diketahui bahwa pohon yang dapat ditanam pada lokasi potensial adalah sebanyak 1.251 batang yang terdiri dari 1.134 pohon kecil dan 117 perdu. Jumlah pohon tambahan yang dapat ditanam pada lokasi potensial memberikan kontribusi bagi lingkungan Kampus Itenas berupa penambahan produksi oksigen dan pemenuhan kebutuhan oksigen populasi kampus yang dapat dilihat pada Tabel 9 berikut.

Tabel 9. Jumlah Produksi Oksigen dan Pemenuhan Kebutuhan Oksigen Populasi Kampus Berdasarkan Penambahan Pohon pada Lokasi Potensial di Itenas

\begin{tabular}{ccccc}
\hline $\begin{array}{c}\text { Jumlah Pohon } \\
\text { Tambahan } \\
\text { (batang) }\end{array}$ & $\begin{array}{c}\text { Produksi Oksigen } \\
\text { Pohon } \\
\text { (gram per hari) }\end{array}$ & $\begin{array}{c}\text { Jumlah Produksi } \\
\text { Oksigen } \\
\text { (gram per hari) }\end{array}$ & $\begin{array}{c}\text { Kebutuhan } \\
\text { Oksigen } \\
\text { Manusia } \\
\text { (gram per hari) }\end{array}$ & $\begin{array}{c}\text { Jumlah Pemenuhan } \\
\text { Kebutuhan Oksigen } \\
\text { Manusia (jiwa) }\end{array}$ \\
\cline { 3 - 3 } $\mathrm{A}$ & $\mathrm{B}$ & $\mathrm{C}$ & $\mathrm{D}$ & $\mathbf{E}$ \\
\hline 1.251 & 1.260 & 1.576 .162 & 864 & $\frac{\mathrm{C}}{\mathrm{D}}$ \\
\hline
\end{tabular}

Berdasarkan perhitungan yang telah dilakukan, dapat diketahui bahwa 1.251 batang pohon yang ditanam pada lokasi potensial di Itenas dapat meningkatkan produksi oksigen sebanyak 1.576 .162 gram per hari yang dapat memenuhi kebutuhan oksigen 1.824 jiwa civitas akademika Itenas. Jika penanaman pohon tersebut dilakukan, maka Itenas akan terasa lebih asri, sejuk, dan segar karena bertambahnya tingkat oksigen yang dihasilkan oleh pohon.

Tabel 10. Analisis Potensi Lahan Vertical Garden dan Roof Garden di Itenas

\begin{tabular}{|c|c|c|c|c|c|}
\hline \multirow{2}{*}{ Lokasi Potensial } & \multirow{2}{*}{$\begin{array}{c}\text { Luas Lahan untuk } \\
\text { Roof Garden }\left(\mathrm{m}^{2}\right)\end{array}$} & \multirow{2}{*}{$\begin{array}{c}\text { Jumlah Vertical } \\
\text { Garden yang dapat } \\
\text { dibangun }\end{array}$} & \multicolumn{2}{|c|}{$\begin{array}{c}\text { Spesifikasi } \\
\text { Vertical Garden }\end{array}$} & \multirow{2}{*}{ Keterangan } \\
\hline & & & Lebar (m) & $\begin{array}{l}\text { Tinggi * } \\
\text { (m) }\end{array}$ & \\
\hline Gedung 1 & 2.342 & 1 & 48 & 12 & Utara \\
\hline Gedung 2 & - & 1 & 23,49 & 12 & Timur \\
\hline \multirow{2}{*}{ Gedung 3} & \multirow{2}{*}{-} & \multirow{2}{*}{2} & 23,45 & 12 & Barat \\
\hline & & & 25,54 & 12 & Timur \\
\hline Gedung 4 & - & 1 & 24 & 6 & Barat \\
\hline \multirow{2}{*}{ Gedung 5} & \multirow{2}{*}{-} & \multirow{2}{*}{2} & 21,62 & 3 & Utara \\
\hline & & & 53,80 & 3 & Barat \\
\hline \multirow{2}{*}{ Gedung 6} & \multirow{2}{*}{-} & \multirow{2}{*}{2} & 24,34 & 3 & Utara \\
\hline & & & 21,68 & 3 & Selatan \\
\hline \multirow{2}{*}{ Gedung 8} & \multirow{2}{*}{-} & \multirow{2}{*}{2} & 23,47 & 9 & Barat \\
\hline & & & 23,47 & 9 & Timur \\
\hline \multirow{2}{*}{ Gedung 9} & \multirow{2}{*}{-} & \multirow{2}{*}{2} & 23,18 & 9 & Barat \\
\hline & & & 23,31 & 9 & Timur \\
\hline Gedung 10 & - & - & - & - & - \\
\hline Gedung 11 & - & 1 & 23,44 & 9 & Selatan \\
\hline Gedung 12 & - & 1 & 23,37 & 9 & Timur \\
\hline Gedung 13 & - & - & - & - & - \\
\hline
\end{tabular}




\begin{tabular}{|c|c|c|c|c|c|}
\hline \multirow{2}{*}{ Lokasi Potensial } & \multirow{2}{*}{$\begin{array}{l}\text { Luas Lahan untuk } \\
\text { Roof Garden }\left(\mathbf{m}^{2}\right)\end{array}$} & \multirow{2}{*}{$\begin{array}{c}\text { Jumlah Vertical } \\
\text { Garden yang dapat } \\
\text { dibangun }\end{array}$} & \multicolumn{2}{|c|}{$\begin{array}{c}\text { Spesifikasi } \\
\text { Vertical Garden }\end{array}$} & \multirow{2}{*}{ Keterangan } \\
\hline & & & Lebar (m) & $\begin{array}{l}\text { Tinggi * } \\
\text { (m) }\end{array}$ & \\
\hline \multirow{2}{*}{ Gedung 14} & \multirow{2}{*}{-} & \multirow{2}{*}{2} & 23,46 & 9 & Utara \\
\hline & & & 23,46 & 9 & Selatan \\
\hline \multirow{2}{*}{ Gedung 15} & \multirow{2}{*}{-} & \multirow{2}{*}{2} & 23 & 9 & Utara \\
\hline & & & 15 & 9 & Selatan \\
\hline Gedung 16 & - & - & - & - & - \\
\hline \multirow{2}{*}{ Gedung 17} & \multirow{2}{*}{-} & \multirow{2}{*}{2} & 24 & 9 & Barat \\
\hline & & & 24 & 9 & Timur \\
\hline Gedung 18 & 1.152 & 1 & 24 & 9 & Barat \\
\hline Gedung 19 & - & 1 & 22,67 & 9 & Barat \\
\hline Gedung 20 & - & 1 & 22,04 & 12 & Barat \\
\hline \multirow{2}{*}{ Gedung 21} & \multirow{2}{*}{-} & \multirow{2}{*}{2} & 23,58 & 12 & Barat \\
\hline & & & 23,64 & 12 & Timur \\
\hline Student Center (SC) & - & 1 & 38,86 & 3 & - \\
\hline Klinik & - & - & - & - & - \\
\hline Cafetaria & - & - & - & - & - \\
\hline Lapangan Tenis & - & - & - & - & - \\
\hline Masjid & - & - & - & - & - \\
\hline Lahan Parkir Masjid & - & - & - & - & - \\
\hline Total & 3.494 & 26 & 693,87 & 231 & - \\
\hline
\end{tabular}

Keterangan:

* Tinggi setiap lantai bangunan adalah 3 meter

Setelah perhitungan potensi lahan ruang terbuka hijau dilakukan, dapat diketahui bahwa Itenas belum dapat memenuhi kebutuhan ruang terbuka populasi kampus. Selain melakukan penambahan lahan untuk memenuhi kebutuhan ruang terbuka populasi kampus, lahan kosong di Itenas dapat dimanfaatkan secara optimal melalui pembuatan vertical garden pada sisi bangunan dan roof garden pada atap bangunan yang memungkinkan untuk dibangun taman. Lebih jelasnya, dapat dilihat pada Tabel 10.

Berdasarkan hasil observasi yang telah dilakukan, dapat diketahui beberapa lokasi potensial berupa lahan kosong yang tidak dimanfaatkan secara optimal sehingga pada lokasi tersebut dapat dibangun vertical garden dan roof garden. Terdapat 27 lokasi potensial untuk pembangunan vertical garden dengan lebar total 693,87 meter dan tinggi total 231 meter. Tidak semua sisi bangunan pada gedung di Itenas memiliki potensi untuk dibangun vertical garden, yang disebabkan oleh adanya jendela maupun berada pada kondisi yang tidak memungkinkan untuk dibangun vertical garden.

Gedung 1 (Desain) dan gedung 18 (Teknik Geodesi) merupakan gedung yang memungkinkan untuk dibangun roof garden karena memiliki dak atau atap yang datar, dengan luas total $3.494 \mathrm{~m}^{2}$. Namun demikian, atap gedung 1 dan gedung 18 perlu dilakukan uji kekuatan struktur atap, uji material kedap air (waterproofing), dan uji lainnya yang diperlukan untuk memastikan bangunan tidak akan rusak atau roboh karena adanya roof garden. 


\section{KESIMPULAN}

Temuan yang didapat dari hasil analisis yang telah dilakukan adalah Kampus Itenas didominasi oleh bangunan seluas $32.762 \mathrm{~m}^{2}(61,87 \%)$, sedangkan luas ruang terbuka hijau adalah $8.395 \mathrm{~m}^{2}(15,85 \%)$ dengan vegetasi yang terdiri dari 539 tanaman pada taman, 309 tanaman pada pot, dan 8 tanaman pada dinding. Kebutuhan Itenas akan ruang terbuka dapat diketahui melalui perhitungan standar penyediaan ruang terbuka pada kawasan pendidikan berdasarkan UI GreenMetric World University Rankings 2018 indikator kelima yaitu sebesar $4 \mathrm{~m}^{2}$ per jiwa, sedangkan penyediaan ruang terbuka di Kampus Itenas adalah sebesar 2,74 $\mathrm{m}^{2}$ per jiwa. Berdasarkan hal tersebut, populasi Kampus Itenas mengalami kekurangan ruang terbuka sebesar $1,26 \mathrm{~m}^{2}$ per jiwa atau secara keseluruhan sebesar $9.295,02 \mathrm{~m}^{2}$.

UI GreenMetric World University Rankings 2018 lebih sesuai untuk diterapkan di Kampus Itenas dibandingkan dengan Metode Gerarkis, karena UI GreenMetric World University Rankings 2018 diperuntukkan bagi kawasan pendidikan khususnya kampus untuk mengetahui usaha berkelanjutan kampus, sedangkan Metode Gerarkis diperuntukkan bagi area perkotaan. Selain itu, hasil perhitungan kebutuhan ruang terbuka hijau berdasarkan Metode Gerarkis dianggap terlalu besar jika diperuntukkan bagi kawasan pendidikan khususnya kampus karena Itenas memiliki kebutuhan ruang terbuka hijau sebesar 325.013,76 $\mathrm{m}^{2}$ atau 62.950,40 $\mathrm{m}^{2}$ (tanpa memperhitungkan kendaraan bermotor) di mana luasan tersebut tidak sesuai dengan kondisi eksisting ruang terbuka hijau pada Kampus Itenas.

Potensi penerapan konsep green campus pada atribut green open space di Itenas dapat diketahui melalui perbandingan antara kebutuhan ruang terbuka hijau dengan ketersediaan lahan bagi peningkatan jumlah tanaman dan taman. Itenas perlu melakukan penambahan ruang terbuka hijau pada beberapa lokasi potensial yang tersebar di Kampus Itenas. Pada lokasi potensial, dapat ditanami 1.251 batang pohon yang terdiri dari 1.134 pohon kecil dan 117 perdu dengan asumsi jarak tanam $2 \times 2$ meter untuk pohon kecil dan $1 \times 1$ meter untuk perdu. Penanaman pohon pada lokasi potensial tersebut dapat meningkatkan produksi oksigen sebanyak 1.576.162 gram per hari yang dapat memenuhi kebutuhan oksigen 1.824 jiwa civitas akademika Itenas. Meskipun penambahan ruang terbuka hijau pada lokasi potensial dilakukan, Itenas perlu melakukan penambahan lahan agar dapat memenuhi kebutuhan ruang terbuka populasi kampus. Selain melakukan penambahan lahan, lahan kosong di Itenas dapat dimanfaatkan secara optimal melalui pembuatan vertical garden pada sisi bangunan dan roof garden pada atap bangunan yang memungkinkan untuk dibangun taman. Upaya penambahan ruang terbuka hijau dapat melibatkan civitas akademika secara luas karena mereka memiliki potensi pengetahuan kepedulian, dan peran aktif yang tinggi.

\section{DAFTAR PUSTAKA}

[1] Union of Conrcerned Scientists, 2007. Global Warming Glossary. [Online] Available at: http://www.climatehotmap.org/global-warming-glossary/g.html [Diakses 1 May 2018].

[2] Direktorat Jenderal Penataan Ruang Departemen Pekerjaan Umum, 2008. Peraturan Menteri Pekerjaan Umum Nomor: 05/PRT/M/2008 Tentang Pedoman Penyediaan dan Pemanfaatan Ruang Terbuka Hijau di Kawasan Perkotaan, Jakarta: Menteri Pekerjaan Umum.

[3] Rocco Pace, G. C., 2016. How green is a "Green City"? A review of existing indicators and approaches. Potsdam: IASS Potsdam.

[4] Roo, M. d., 2011. The Green City Guidelines: Techniques for a healthy liveable city. Netherlands: Urban and Regional Development Landscape Architecture.

[5] UI GreenMetric Ranking Team, 2018. Petunjuk UI GreenMetric World University Rankings 2018, Jakarta: Universitas Indonesia. 
[6] Suryana, 2010. Buku Ajar Perkuliahan Metodologi Penelitian: Model Praktis Penelitian Kuantitatif dan Kualitatif. Bandung: Universitas Pendidikan Indonesia.

[7] Sugiyono, 2018. Metode Penelitian Kuantitatif, Kualitatif dan $R \& D$. Bandung: Alfabeta.

[8] Riduwan, 2015. Skala Pengukuran Variabel-Variabel Penelitian. Bandung: Alfabeta.

[9] Muis, B. A., 2005. Analisis Kebutuhan Ruang Terbuka Hijau Berdasarkan Kebutuhan Oksigen dan Air di Kota Depok Provinsi Jawa Barat. Tesis, p. 19.

[10] Walikota Bandung, 2010. Peraturan Daerah Kota Bandung Nomor 5 Tahun 2010 Tentang Bangunan Gedung , Bandung: Sekretaris Daerah Kota Bandung.

[11] Kementerian Pekerjaan Umum, 2009. Peraturan Menteri Pekerjaan Umum Nomor: 12/PRT/M/2009 Tentang Pedoman Penyediaan dan Pemanfaatan Ruang Terbuka Non Hijau di Wilayah Kota/Kawasan Perkotaan, Jakarta: Menteri Pekerjaan Umum.

[12] Shiddieq, D., Sudira, P. \& T., 2018. Aspek Dasar Agronomi Berkelanjutan. Yogyakarta: Gadjah Mada University Press. 